\title{
ESTIMASI KERUGIAN EKONOMI KERUSAKAN TERUMBU KARANG AKIBAT TABRAKAN KAPAL CALEDONIAN SKY DI RAJA AMPAT
}

\author{
Estimated Economic Loss Of Coral Reefs Due To \\ Ship Caledonian Sky Shipping In King Ampat
}

\author{
${ }^{*}$ Cornelia Mirwantini Witomo, Maulana Firdaus, Permana Ari Soejarwo, \\ Umi Muawanah, Andrian Ramadhan, Radityo Pramoda dan Sonny Koeshendrajana \\ Balai Besar Riset Sosial Ekonomi Kelautan dan Perikanan \\ Gedung Balitbang KP I Lt. 4 \\ Jalan Pasir Putih Nomor 1 Ancol Timur, Jakarta Utara \\ Telp: (021) 64711583 Fax: 64700924 \\ *Email: tone_poenya@yahoo.com
}

Diterima tanggal: 8 April 2017 Diterima setelah perbaikan: 19 Mei 2017

Disetujui terbit: 7 Juni 2017

\begin{abstract}
ABSTRAK
Tujuan dari penelitian ini adalah menghitung kerugian ekonomi rusaknya terumbu karang akibat tabrakan kapal Caledonian Sky di Raja Ampat dan merumuskan kebijakan terkait penanggulangan kerugian ekonomi rusaknya terumbu karang akibat tabrakan. Metode yang digunakan dalam penelitian ini adalah studi literatur dengan mengkaji berbagai literatur, data pendukung serta hasil studi yang telah dilakukan oleh berbagai pihak terutama yang berhubungan dengan penelitian. Analisis data yang digunakan mengacu pada PERMEN Lingkungan Hidup No 7 Tahun 2014 tentang Kerugian Lingkungan Hidup Akibat Pencemaran dan/ atau Kerusakan Lingkungan Hidup. Data yang diperoleh dari hasil penelusuran literatur selanjutnya dianalisis menggunakan metode benefit transfer. Analisis lainnya adalah analisis habitat equivalent analysis yang menghitung ukuran atau skala proyek restorasi yang dibutuhkan untuk mengembalikan layanan sumberdaya ke kondisi awal dan analisis deskritif yang dilakukan terhadap angka yang didapat dari hasil analisis dan sebagai dasar estimasi besaran kerugian yang diklaim oleh pemerintah Indonesia terhadap pihak Kapal Caledonian Sky. Berdasarkan hasil analisis estimasi jumlah kerugian ekonomi rusaknya terumbu karang akibat tabrakan Kapal Pesiar Caledonian Sky di Raja Ampat sebesar 23 juta USD dengan luasan terdampak $18.882 \mathrm{~m}^{2}$ dan rekomendasi kebijakan yang dapat diambil sebagai opsi pemerintah untuk menghadapi kerusakan terumbu karang akibat tabrakan Kapal Pesiar Caledonia Sky adalah mempertimbangkan untuk mengadakan negosiasi penyelesaian sengketa tentang tuntutan kerugian kepada perusahaan kapal pesiar Inggris Caledonian Sky atas rusaknya terumbu karang diluar pengadilan dan mempertimbangkan langkah hukum untuk menuntut ganti rugi kepada perusahaan kapal pesiar Inggris Caledonian Sky sesuai dengan hukum yang berlaku di Indonesia.
\end{abstract}

Kata Kunci: kerugian, terumbu karang, Raja Ampat

\begin{abstract}
This study aims to calculate the economic loss of coral damage due to collision of Caledonian Sky cruise vessels in Raja Ampat and formulate policies related to the economic loss mitigation of coral damage due to collision. The method that used in this study is study of literature by reviewing various literature, supporting data and study results that have been done by various parties and related to this study. The data analysis that is used refers to Regulation Minister of Environment No. 7 of 2014 on Environmental Losses Due to Pollution and/or Environmental Degradation. Data that are obtained from literature searching results then analyzed by using benefit transfer method. Another analysis is the habitat equivalent analysis that calculate the size or scale of the restoration project that needed to return resource services to initial conditions and descriptive analysis of the figures that obtained from the analysis and as a basis for estimating the amount of losses that claimed by the Indonesian government against the Caledonian Sky cruise vessel. Based on the results of the estimation analysis, the amount of economic loss from coral damage due to the collision of Caledonian Sky Cruise vessel in Raja Ampat is 23 million USD with an affected area of 18,882 $\mathrm{m}^{2}$. The policy recommendations that can be taken as the government option to deal with coral reef damage due to collision of Caledonia Sky Cruise is considering negotiation on the settlement of disputes concerning the claims of losses to British cruise vessel Caledonian Sky on the destruction of coral reefs outside the court and considering legal action to indemnify the British cruise vessel corporation Caledonian Sky in accordance with Indonesian law.
\end{abstract}

Keywords: loss, coral reef, Raja Ampat 


\section{PENDAHULUAN}

Secara umum, penghitungan kerugian lingkungan hidup akibat pencemaran dan/ atau kerusakan lingkungan hidup merupakan pemberian nilai moneter terhadap dampak pencemaran dan/atau kerusakan lingkungan hidup. Besaran nilai moneter kerugian ekonomi lingkungan hidup sekaligus merupakan nilai ekonomi kerugian lingkungan hidup yang harus dibayarkan kepada pihak yang dirugikan oleh pihak yang melakukan pencemaran dan/atau kerusakan lingkungan hidup.

Kerusakan lingkungan telah menjadi ancaman bagi mahluk hidup termasuk di dalamnya manusia walaupun secara langsung kerusakan lingkungan adalah akibat perilaku manusia untuk memanfaatkan barang dan jasa lingkungan dalam rangka memenuhi kebutuhan hidup manusia. Secara konstitusional terdapat norma hukum yang melindungi masyarakat untuk mendapatkan lingkungan hidup yang baik dan sehat dan ini harus dilakukan oleh negara. Hal ini tertuang dalam UUD 1945 Pasal $28(h)$.

Dalam konteks regional Kawasan Konservasi Laut Raja Ampat masuk dalam kawasan segitiga karang dunia dan merupakan kawasan penting keanekaragaman hayati pesisir dan laut. Raja Ampat memiliki potensi karang dan ikan karang dengan kondisi secara umum masih baik serta pemandangan pantai dan pulau-pulau yang indah hal ini yang menjadikan Raja Ampat sebagai salah satu tujuan wisata laut seperti menyelam dan snorkeling yang banyak dikunjungi oleh wisatawan lokal dan mancanegara. Data dari tahun ke tahun adanya peningkatan jumlah kunjungan wisatawan ke Raja Ampat dan secara langsung memberikan kontribusi ekonomi terhadap Raja Ampat baik dari tiket masuk, akomodasi, restoran, penyewaan alat selam dan perahu.

Raja Ampat sudah memiliki pedoman pengelolaan kawasan konservasi yang menggunakan pendekatan zonasi yang ditetapkan oleh Menteri Kelautan Perikanan dalam Kepmen KP Nomor 63/Kepmen KP/2014. Zonasi tersebut memasukan kriteria seperti persentase habitat penting yang dilindungi sekitar 30\% serta secara sosial ekonomi sejauh mungkin zona inti jauh dari permukiman penduduk. Dengan adanya zonasi tersebut dapat mengatur kegiatan masyarakat seperti penangkapan ikan termasuk pariwisata yang dapat dilakukan pada area tertentu di perairan Raja Ampat. Dengan tingginya jumlah kunjungan wisatawan secara tidak langsung memberikan resiko terhadap kerusakan lingkungan khususnya ekosistem terumbu karang. Saat ini dengan kecanggihan dunia maya dan kemudahan bertransaksi secara online banyak agen wisata yang menawarkan wisata ke Raja Ampat baik lewat udara dengan pesawat terbang transit Sorong lalu dilanjutkan dengan kapal cepat ke Raja Ampat maupun lewat laut dengan menggunakan kapal pesiar langsung menuju ke Raja Ampat. Berbagai macam tawaran paket-paket wisata membawa dampak tingginya jumlah kunjungan wisata dengan pangsa wisatawan tertentu.

Caledonian Sky adalah salah satu penyedia Kapal Pesiar yang memiliki paket wisata dengan salah satu destinasi wisata yang ditawarkan adalah Raja Ampat. Caledonian Sky sudah tiga kali melakukan pelayaran ke Raja Ampat namun pelayaran keempat pada tanggal 4 Maret 2017 mengalami kecelakaan karena kandas sehingga menabrak terumbu karang. Pada saat kejadian otoritas Pemerintah Kabupaten Raja Ampat langsung berkomunikasi dengan pihak Caledonian Sky dan berjanji akan bertanggung jawab dengan membuat berita acara akan siap mengganti kerugian ekonomi rusaknya terumbu karang akibat tabrakan Kapal Caledonian Sky. Berdasarkan hal tersebut, pemerintah harus segera melakukan penghitungan sebagai bentuk tindak lanjut kejadian tersebut agar segera dapat diproses secara perdata berupa klaim ganti rugi. Berdasarkan hal yang diungkapkan sebelumnya tujuan dari penelitian ini adalah menghitung kerugian ekonomi rusaknya terumbu karang akibat tabrakan Kapal Caledonian Sky di Raja Ampat dan merumuskan kebijakan terkait komponen biaya yang digunakan untuk menghitung kerugian ekonomi rusaknya terumbu karang akibat tabrakan. 


\section{METODOLOGI}

\section{Waktu dan Lokasi Penelitian}

Penelitian dilakukan pada bulan Maret 2017 dan berlokasi di DKI Jakarta.

\section{Jenis dan Sumber Data}

Jenis data yang digunakan dalam penelitian ini adalah data sekunder. Data sekunder yang dimaksud adalah data-data yang diperoleh dari hasil penelitian terdahulu yang terkait dengan penelitian ini. Data yang digunakan adalah nilai manfaat dan nilai bukan manfaat yang dimiliki oleh ekosistem terumbu karang. Nilai manfaat meliputi nilai manfaat langsung berdasarkan aktivitas masyarakat di perairan Raja Ampat yaitu perikanan tangkap dan pariwisata. Nilai manfaat tidak langsung diperolehdari fungsi ekologi dari ekosistem terumbu karang seperti proteksi pesisir dan habitat. Untuk nilai bukan manfaat adalah nilai sosial budaya meliputi nilai terhadap keberadaan ekosistem terumbu karang dan nilai warisan ekosistem terumbu karang yang diturunkan kepada anak cucu.

\section{Jenis dan Sumber Data}

Data yang digunakan dalam penelitian ini adalah data sekunder dan data primer. Data sekunder diperoleh dari beberapa sumber yang diantaranya adalah dokumen-

dokumen yang dimiliki Dinas Kelautan dan Perikanan Kabupaten Jepara, Badan Pusat Statistik Kabupaten Jepara, Kecamatan, Balai Taman Nasional Karimunjawa dan berbagai publikasi ilmiah. Data primer diperoleh melalui wawancara langsung kepada nelayan dan pemangku kepentingan terkait.

\section{HASIL DAN PEMBAHASAN}

\section{Kondisi Umum Wilayah Karimunjawa}

Kecamatan Karimunjawa adalah salah satu kecamatan di Kabupaten Jepara yang berupa wilayah kepulauan dengan luas wilayah $71,20 \mathrm{~km}^{2}$. Kecamatan ini terdiri dari 4 desa yaitu Desa Karimunjawa, Desa Kemojan, Desa Parang dan Desa Nyamuk dengan jumlah penduduk pada tahun 2013 sebanyak 9016 jiwa (BPS Kab. Jepara, 2014). Berdasarkan SK Menhut No.161/ Menhut/ II/ 88, kawasan Kepulauan Karimunjawa ditetapkan sebagai Taman Nasional Karimunjawa dikelola untuk tujuan pelestarian, perlindungan, penelitian, pendidikan dan pariwisata.

Kepulauan Karimunjawa sebagai kawasan Taman Nasional memiliki keanekaragaman biota laut seperti ikan hias/ ikan karang, terumbu karang, dan berbagai biota karang lainnya. Namun, aktivitas penangkapan yang tidak ramah lingkungan mengancam kelestariannya. Dengan adanya status Kawasan Taman Nasional ini, tekanan terhadap sumberdaya tersebut secara perlahan dapat dikurangi.

\section{Karakteristik dan Kalender Penangkapan Ikan di Karimunjawa}

Masyarakat di kawasan Karimunjawa telah lama memanfaatkan sumberdaya perikanan sebagai salah satu sumber penghidupan mereka. Sumberdaya tersebut dimanfaatkan baik

\section{Metode Pengumpulan Data}

Metode yang digunakan dalam kajian ini adalah desk study. Dengan metode desk study, mengkaji berbagai literatur, data pendukung serta hasil studi yang telah dilakukan oleh berbagai

Tabel 1. Jenis dan Sumber Data Sekunder Penelitian.

\begin{tabular}{cllr} 
No & \multicolumn{1}{c}{ Jenis Data } & \multicolumn{1}{c}{ Sumber } & Nilai (Rp/Ha) \\
\hline 1. & Penangkapan Ikan & Ramadhan et al. (2015) & $6,844,354$ \\
2. & Pariwisata & PRL (2015) & $411,380,357$ \\
3. & Proteksi Lingkungan Pesisir & Ramadhan et al. (2015) & $59,132,987$ \\
4. & Habitat Sumbedaya Ikan & Barbier et al., (2011) & $6,075,000$ \\
5. & Sosial Budaya & Ramadhan et al., (2015) & $74,738,247$ \\
\hline
\end{tabular}

Sumber: Ramadhan et al. (2015); Pengelolaan Ruang Laut (2015) dan Barbie et al. (2011) 
pihak terutama yang berhubungan dengan kegiatan kajian yang akan dilakukan. Dengan kata lain penelitian yang dilakukan adalah penelitian kepustakaan yang digunakan oleh peneliti untuk menganalisis data yang diperoleh dari dokumen literatur (Wirartha, 2006).

\section{Metode Analisis Data}

Metode yang digunakan dalam perhitungan ini adalah mengacu pada Peraturan Menteri Lingkungan Hidup (Permen LH) No 7/2014 tentang Kerugian Lingkungan Hidup Akibat Pencemaran dan/atau Kerusakan Lingkungan Hidup. Jenis kerugian dapat digolongkan menjadi beberapa jenis tertuang dalam Tabel 2 .

Data yang diperoleh dari hasil penelusuran literatur selanjutnya dianalisis menggunakan metode benefit transfer adalah metode analisis yang digunakan untuk mengukur nilai jasa ekonomi dari pemanfaatan untuk aktivitas ekonomi masyarakat dengan melihat nilai ekonomi di lokasi lain dengan karakteristik yang sama. Benefit transfer adalah salah satu komponen yang digunakan untuk analisis biaya manfaat dalam skala besar. Teknik benefit transfer adalah fungsi yang menggambarkan hubungan antara estimasi nilai dan karakteristik terukur lainnya dengan lokasi lainnya atau konteks lainnya.

Analisis Habitat Equivalent Analysis adalah perhitungan ukuran atau skala per proyek restorasi yang dibutuhkan untuk mengembalikan layanan sumber daya ke kondisi awal (Fauzi, 2014). Ada tiga tahapan utama yang dilakukan yakni: (1) Menghitung besaran debit; (2) Menghitung besaran kredit; dan (3) Perhitungan skala dan biaya restorasi. Debit adalah jumlah kerusakan yang terjadi sepanjang waktu yang menggambarkan service loss/ kehilangan layanan. Kredit adalah manfaat yang dihasilkan dari proyek restorasi yang menggambarkan service gain/ manfaat layanan.

Perhitungan debit: informasi terkait dengan jenis habitat/ ekosistem rusak, derajat atau tingkat kerusakannya.

$$
P V D=\sum_{t_{D}=0}^{t_{D}} L_{t}(1
$$

Keterangan:

$$
\begin{aligned}
\mathrm{Lt}= & \begin{array}{l}
\text { Besaran kerugian antara (interim loss } \\
\text { (luas terdampak) }
\end{array} \\
\mathrm{r}= & \text { Discount rate }(3 \%) \\
\mathrm{t}_{0}= & \text { Waktu awal kejadian (terjadinya kerusa- } \\
& \text { kan terumbu karang (2017) } \\
\mathrm{t}_{\mathrm{D}}= & \begin{array}{l}
\text { Waktu akhir kerugian antara atau } \\
\text { waktu restorasi yang dibutuhkan sampai } \\
\text { kembali ke tingkat awal (10 tahun) }
\end{array}
\end{aligned}
$$

Perhitungan kredit: informasi terkait skenario persen layanan ekosistem terumbu

\begin{tabular}{|c|c|c|}
\hline No & Jenis Kerugian & Penjelasan \\
\hline 1. & $\begin{array}{l}\text { Kerugian untuk pengantian biaya pelaksanaan } \\
\text { penyelesaian sengketa lingkungan hidup }\end{array}$ & $\begin{array}{l}\text { Biaya verifikasi lapang } \\
\text { Analisa Laboratorium } \\
\text { Ahli dan Pengawasan Pelaksanaan Pembayaran } \\
\text { Kerugian Lingkungan Hidup }\end{array}$ \\
\hline 2. & $\begin{array}{l}\text { Kerugian untuk pengganti biaya } \\
\text { penanggulanggan kerusakan dan pemulihan } \\
\text { lingkungan hidup }\end{array}$ & $\begin{array}{l}\text { Biaya Penanggulangan } \\
\text { Biaya Pemulihan }\end{array}$ \\
\hline 3. & Kerugian Ekosistem & Nilai manfaat ekologi dan sosial budaya \\
\hline 4. & Kerugian Masyarakat & Nilai manfaat ekonomi \\
\hline
\end{tabular}
karang yang akan dipulihkan serta waktu yang dibutuhkan untuk pemulihan dan manfaat setelahnya.

$$
P V C=\sum \quad S_{t}(1+\mathrm{r})
$$

Keterangan

$$
\begin{aligned}
\text { St }= & \text { Manfaat (service) yang dipulihkan pada } \\
& \text { periode ke-t (dalam persen untuk kasus } \\
& \text { HEA) dari program restorasi }
\end{aligned}
$$

Tabel 2. Jenis Kerugian yang Dihitung Sebagai Dasar Komponen Biaya Dalam Estimasi Kerugian Ekonomi Rusaknya Terumbu Karang Akibat Tabrakan Caledonian Sky, 2017.

Sumber: Diacu dari Peraturan Menteri Lingkungan Hidup No. 7 Tahun 2014 
tc = Waktu akhir layanan ekosistem terumbu karang secara penuh diperoleh atau waktu yang dibutuhkan oleh ekosistem untuk memberikan layanan (jasa ekosistem) seperti semula (25 tahun recovery 100\%)

Discounted SuY Gained Per unit/ (PVC per unit $)=\frac{P V C}{L_{t}}$

Perhitungan skala restorasi besaran kompensasi yang dibutuhkan diperoleh dari pembagian debit dan kredit.

$$
\begin{aligned}
& \text { Skala Restorasi (Replacement Habitat } \\
& \text { Size) }=\frac{\sum_{t_{D}=0}^{t_{D}} P V D_{t}}{\sum_{t_{D}=0}^{t_{D}} \text { disc } P V C_{t}}
\end{aligned}
$$

Keterangan:

PVDt $=$ Present Value Debit at time $t$

discPVCt $=$ Present Value Credit at time $t$

Discounting adalah prosedur ekonomi yang mentransformasi aliran monetaryl uang yang terjadi antar waktu maupun pada waktu tertentu pada suatu nilai yang setara saat ini. Dapat juga diartikan bahwa discounting adalah menentukan nilai kini dari manfaat dan biaya akan terjadi di masa mendatang melalui pembobotan yang disebut discount factor adalah:

Keterangan:

$$
d f=\frac{1}{(1+r)}
$$

$$
\begin{array}{ll}
d f & =\text { Discount factor } \\
r & =\text { Discount rate }
\end{array}
$$

Analisis deskriptif dilakukan terhadap angka yang didapatkan dari hasil analisis. Secara umum itu adalah angka estimasi yang digunakan sebagai dasar klaim pemerintah Indonesia kepada pihak asuransi atau perusahan Kapal Caledonian Sky.

\section{HASIL DAN PEMBAHASAN}

Kronologis Kerusakan Terumbu Karang Akibat Tabrakan Kapal Caledonia Sky di Raja Ampat

Pada tanggal 3 Maret 2017 pukul 23.00 WIT kapal pesiar MV Caledonian Sky yang berbendera Bahama dengan membawa 79 kru dan 102 wisatawan dari berbagai negara, tiba di perairan Desa Yonwaupnor, Distrik (Kecamatan) Moenmansar merupakan salah satu kawasan konservasi perairan daerah (KKPD) Selat Dampier. Kelengkapan dokumen kapal telah diperiksa dan diberikan izin masuk melalui surat persetujuan berlayar dari kantor syahbandar Otoritas Pelabuhan (KSOP) Jayapura Nomor CC.2/KM.17/02/III/2017 tanggal 1 Maret 2017 menuju Raja Ampat. Esok harinya pada tanggal 4 Maret 2017 tim bea cukai, imigrasi, karantina dan syahbandar naik ke atas kapal untuk melakukan pemeriksaan sesuai dengan izin yang ada untuk bertolak menuju Bitung sesuai dengan SPB dari Syahbandar UPP Saonek Tanggal 4 Maret 2017. Wisatawan sejak subuh sudah menikmati atraksi wisata Raja Ampat hingga pukul 12 siang. Kejadian tabrakan kapal pesiar Caledonian Sky terjadi pada pukul 12.41. Kapal pesiar MV Caledonian Sky dengan tonase GT 4200 berbendera Bahama berlayar menuju Bitung dengan kecepatan 9,5 knot kemudian mengalami kandas dan menabrak terumbu karang pada kedalaman 5 meter di perairan Pulau Kri (Kampung Yenbuba) Kecamatan Moesmnswar Selat Dampier di dalam zona pemanfaatan terbatas kawasan konservasi daerah kepulauan Raja Ampat yang ditetapkan oleh Menteri Kelautan dan Perikanan Nomor: 36/ KEPMEN-KP/2014 tentang Penetapan Taman Wisata Perairan Kepulauan Raja Ampat.

Menurut pernyataan kapten kapal MV Caledonian Sky, kandasnya kapal ini disebabkan kapten kapal hanya memonitor GPS dan Radar dan tanpa memperhitungkan Pasang surut air laut dan kondisi alam perairan di sekitarnya. Antara pukul 16.00-17.00 WIT tim terpadu (Basarnas, Unit penyelenggara Pelabuhan Saonek, Badan Layanan Umum Daerah-Unit Pelayanan Teknis Daerah Kawasan Konservasi Perairan, Dinas Pariwisata Kabupaten Raja Ampat dibantu dengan operator wisata) tiba di lokasi kapal pesiar selanjutnya melaksanakan koordinasi dengan kapal tug boat yang berlokasi di Kota Waisai. Kemudian Pukul 18.30 WIT kapal Tug Boat Audreyob Tanjang Priok tiba di lokasi dan melakukan proses penarikan kapal namun tidak berhasil sehingga kapal pesiar tersebut berusaha untuk keluar tanpa bantuan tug boat, proses ini selesai pada pukul 23.15 WIT. 
Pada hari minggu 5 Maret 2017 titik koordinat kapal berlabuh 00'29"5540 LS dan 130'43"3561 BT di depan kampung Yenyafnor pada jam 16.25 WIT dilakukan penyelaman oleh UPP Saonek untuk mengecek lunas dari kapal dan memastikan kapal dalam keadaan aman. Hasil penyelaman ditemukan hal sebaga berikut: terdapat goresan-goresan ringan di depan, tengah dan belakang lunas kapal. Surat Persetujuan berlayar diterbitkan pada tanggal 5 maret 2017 pada pukul 21.00 WIT Nomor BB/10/23/2017 setelah ada surat kesepakatan antara Kapten Kapal dengan pemerintah distrik dan BLUD UPTD KKP Raja Ampat disaksikan oleh agen lokal (PT Pertamina Trans Kontinental) dan general agent (PT Andhika Lines) mengenai kerugian yang muncul dari insiden ini akan diselesaikan melalui asuransi.

Beberapa upaya yang telah dilakukan seperti pada tanggal 5 Maret 2017 pukul 11.0014.30 WIT tim dari BLUD UPTD KKP Raja Ampat melakukan penyelaman untuk melihat kerusakan terumbu karang di lokasi kandasnya kapal. Kemudian pada tanggal 8-9 Maret 2017 Tim Universitas Papua (UNIPA)), BLUD UPTD KKP Raja Ampat, Conservation International, The Nature Conservacy dan operator wisata telah melakukan survey kerusakan kedua. Pada Tanggal 13 Maret 2017 tim gabungan (Kemenko Maritim, KKP, Dinas Pariwisata Raja Ampat, Badan Layanan Umum Daerah Unit Pelayanan Teknis KKP Raja Ampat, Polair, UPP Saonek, DKP Raja Ampat) melakukan ground check ke lokasi kejadian yang kemudian dilanjutkan pada pukul 17.00-22.00 WIT rapat koordinasi di kantor BLUD UPTD KKP Raja Ampat yang dihadiri oleh Kemenko Bidang Kemaritiman, KKP, Dinas Pariwisata Raja Ampat, BLU Daerah Unit pelayanan Teknis Daerah Kawasan Konservasi Perairan Raja Ampat, Polisi perairan Raja Ampat, Unit Penyelenggaraan Pelabuhan Saonek, Dinas Kelautan dan Perikanan Raja Ampat dan Kementerian Lingkungan Hidup dan Kehutanan.

\section{Metode Penghitungan Kerugian Ekonomi}

Jika mengacu pada Keputusan Menteri Lingkungan Hidup Nomor 7 Tahun 2014 tentang Kerugian Lingkungan Hidup Akibat Pencemaran dan/atau Kerusakan Lingkungan Hidup komponen penghitungan terdiri dari sebagai berikut

\section{Pelaksanaan penyelesaian sengketa lingkungan hidup}

Biaya pelaksanaan penyelesaian sengketa lingkungan hidup terdiri dari biaya verifikasi lapangan, analisa laboratorium dan biaya tenaga ahli dan pengawasan pelaksanaan pembayaran kerugian. Nilai biaya pada komponen ini adalah biaya riil pengeluaran untuk melaksanakan kegiatan tersebut berdasarkan kesepakatan antar pihak yang bersengketa.

\section{Pemulihan/Restorasi}

\section{a. Biaya Operasional Restorasi}

Biaya operasional restorasiterumbu karang menurut Edwards dan Gomez (2007), terdiri dari : (1) Pengumpulan dan transplantasi karang pada struktur buatan; (2) Pengumpulan dan transportasi koloni-koloni besar dan bercabang; (3) Pembuatan kebun terumbu karang termasuk 11 struktur buatan; dan (4) Monitoring periode pembuatan/ transplantasi karang.

\section{b. Biaya Restorasi Lingkungan Hidup (Terumbu karang)}

Pendekatan yang digunakan untuk menghitung nilai kompensasi terhadap kerusakan lingkungan (terumbu karang) adalah dengan menggunakan habitat equivalency analysis (HEA). HEA adalah perhitungan ukuran atau skala per proyek restorasi yang dibutuhkan untuk mengembalikan layanan sumber daya ke kondisi awal (Fauzi, 2014). Ada tiga tahapan utama yang dilakukan yakni: (1). Menghitung besaran debit; (2). Menghitung besaran kredit; dan (3). Perhitungan skala dan biaya restorasi. Debit adalah jumlah kerusakan yang terjadi sepanjang waktu yang menggambarkan service loss/ kehilangan layanan. Kredit adalah manfaat yang dihasilkan dari proyek restorasi yang menggambarkan service gain/ manfaat layanan. Satuan yang digunakan penghitungan kasus di Raja Ampat adalah luasan area terdampak sebesar 1,8882 ha (Press Release 21 Maret 2017). Skala restorasi adalah besaran 
kompensasi yang dibutuhkan diperoleh dari pembagian debit (kehilangan layanan) dengan kredit (manfaat layanan). Untuk satuan biaya restorasi menggunakan nilai USD 12.960 .000 per hektar sama dengan nilai yang digunakan untuk mengestimasi kerusakan terumbu karang oleh Palau Siren di Koron State Southern Lagoon (Gouze et al., 2014).

Dasar pemilihan nilai tersebut Filipina sebagai negara berkembang dan karakteristik The Rock Island Souhtern Lagoon (RISL), Filipina sama dengan Raja Ampat, Indonesia sebagai daerah konservasi yang memiliki kegiatan penangkapan, pariwisata yang dikelola berdasarkan zonasi. Satuan biaya restorasi RISL merujuk pada lokasi Tubbataha Reef National Park, Palawan Filipina dengan memasukkan biaya modal dan biaya tenaga kerja (Rosales, 2006). Biaya modal terdapat pada biaya pra konstruksi dan biaya kontruksi termasuk di dalamnya biaya operasional restorasi meliputi material, peralatan, honor, dan biaya administrasi lainnya. Sedangkan untuk biaya tenaga kerja meliputi tenaga kerja supervisi, fasilitator, pengajar serta pekerja ketika proses restorasi berlangsung.

Berdasarkan Tabel 3 menggambarkan luasan terdampak 1.8882 ha dengan tingkat kerusakan yang berbeda. Tingkat kerusakan $90 \%$ luas areal terdampak sebesar 1,3270 ha sedangkan tingkatkerusakan $50 \%$ luas terdampak sebesar 0.5612 (Rapat Koordinasi April 2017). Untuk tingkat kerusakan 90\% dengan luas terdampak 1,3270 ha akan kehilangan barang dan jasa lingkungan/ service lost total sebanyak 11,6592 ha sedangkan dengan luas 0,5612 ha dengan tingkat kerusakan $50 \%$ maka kehilangan barang dan jasa lingkungan/ service lost total sebanyak 4,9308 ha, yang dihitung dari 10 tahun proyek restorasi. Hasil penelitian dari MacNeil et al.,(2015), menunjukkan bahwa waktu yang dibutuhkan ekosistem terumbu karang untuk kembali pulih $100 \%$ adalah 25 tahun. Setelah tahun ke-10 proyek restorasi terus berjalan hingga 25 tahun dan pemulihan kembali ke posisi baseline $(100 \%)$. Diasumsikan discount factor adalah $3 \%$ (discounted factor terhadap sumberdaya $3 \%$ - 7\%, Office Management of Budget, USA). Kemudian diperoleh total nilai barang dan jasa lingkungan/ service gain selama 25 tahun restorasi sebanyak 24,2902 ha untuk luas areal 1,3270 ha dan 14,2295 ha untuk luas areal 0,5612 ha. Nilai manfaat yang diperoleh setelah 25 tahun tersebut harus discounted dengan luasan terdampak tahun 2017. Hal ini dilakukan sebagai prosedur ekonomi yang mentransformasikan aliran uang dalam hal ini luasan terdampak yang terjadi antar waktu maupun pada waktu tertentu pada suatu niai yang setara saat ini dalam hal ini besaran nilai manfaat tahun 2017 dibandingkan dengan besaran nilai manfaat 60 tahun kemudian. Dengan diketahuinya nilai kredit besaran skala restorasi sebesar 1,290 ha maka diperoleh biaya restorasi ekosistem terumbu karang yang dikalikan dengan satuan biaya restorasi yang diacu.

\section{c. Monitoring Proyek Restorasi}

Monitoring dalam jangka waktu tertentu penting dilakukan untuk mengetahui apakah proses restorasi tersebut berhasil. Dalam satu waktu proses monitoring secara umum terbagi menjadi baseline/ pra proyek, implementasi tengah proyek, post-project implementasi dan fase penilaian. Salah satu kriteria yang termonitor dalam proses restorasi adalah tingkat kelangsungan hidup/ survival rate. Tercatat oleh Bayraktarov et al. (2016), tingkat kelangsungan

Tabel 3. Perhitungan HEA Menurut Luasan Total.

\begin{tabular}{ccccccr}
\hline $\begin{array}{c}\text { Total } \\
\begin{array}{c}\text { Kerusakan } \\
\text { (ha) }\end{array}\end{array}$ & $\begin{array}{c}\text { Total SUY } \\
\text { Lost } \\
\text { (ha) }\end{array}$ & $\begin{array}{c}\text { Total } \\
\text { SUY } \\
\text { Gain } \\
\text { (ha) }\end{array}$ & $\begin{array}{c}\text { Discounted } \\
\text { SUYs Gained } \\
\text { per unit } \\
\text { (ha) }\end{array}$ & $\begin{array}{c}\text { Replacement } \\
\text { Habitat Size } \\
\text { (ha) }\end{array}$ & $\begin{array}{c}\text { Biaya Restorasi } \\
\text { (Rp) }\end{array}$ & $\begin{array}{c}\text { Restorasi } \\
\text { (USD) }\end{array}$ \\
\hline 1.3270 & 11.6592 & 24.2902 & 18.3046 & 0.6370 & $157,319,855,785$ & $11,653,323$ \\
0.5612 & 4.9308 & 14.2295 & 25.3554 & 0.1945 & $48,030,789,035$ & $3,557,836,225$ \\
1,8882 & & & & & $205,350,644,820$ & $15,211,159$ \\
\hline
\end{tabular}

Sumber : Rosales, 2006 
hidup terumbu karang adalah 65\%. Dengan adanya monitoring dapat memberikan penilaian apakah proyek restorasi tersebut berhasil berdasarkan indikator-indikator yang sudah disusun sebelumnya (Gambar 1).

Monitoring atau dengan kata lain pengawasan masuk dalam tata rehabilitasi wilayah pesisir dan pulau-pulau kecilyang tertuang dalam Permen KP Nomor 24/Permen-KP/2016. Ruang lingkup dari peraturan menteri ini meliputi perencanaan, pelaksanaan dan pemeliharaan rehabilitasi. Perencanaan rehabilitasi dilakukan melalui kegiatan identifikasi penyebab kerusakan; identifikasi tingkat kerusakan dan penyusunan rencana rehabilitasi. Dalam kasus yang terjadi di Raja Ampat perencanaan dilakukan pada tahun 1-2 tahun dan dilanjutkan dengan pelaksanaan rehabilitasi. Pemeliharaan sebagai bentuk menjaga dan mempertahankan komponen biotik ekosistem.

\section{Kerugian Ekosistem}

Untuk memperoleh besaran kompensasi terhadap kerugian ekosistem yaitu dengan menggunakan pendekatan valuasi ekonomi. Nilai yang diukur adalah manfaat ekonomi ekosistem terdiri dari, proteksi lingkungam pesisir, habitat sumberdaya ikan dan sosial budaya. Komponen estimasi perhitungan kerusakan terumbu karang dihitung dari total economic value (TEV). Pendekatan yang digunakan yaitu, Replacement Cost Method, Benefit Transfer dan Contingent Valuation Method (Tabel 5).

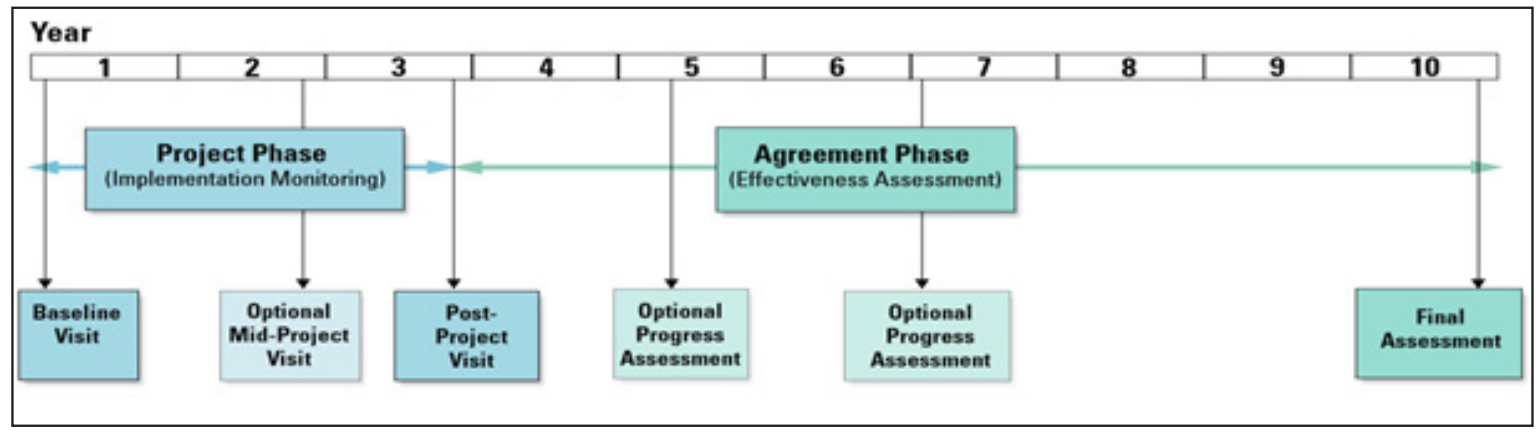

Gambar 1. Timeline Monitoring Dalam Proses Restorasi dalam Jangka Waktu 10 Tahun.

Sumber: Woodward and Kathy (2011)

Tabel 4. Perhitungan Kerugian Ekosistem.

\begin{tabular}{lclrr}
\hline \multicolumn{1}{c}{ Nilai Pemanfaatan } & $\begin{array}{c}\text { (Rp/Ha/Tahun } \\
\mathbf{2 0 1 7 )}\end{array}$ & \multicolumn{1}{c}{ Sumber } & $\begin{array}{r}\text { Untuk Luasan } \\
\text { 1,8882 Ha (Rp) }\end{array}$ & USD \\
\hline Proteksi Lingkungan Pesisir & $69,110,869$ & Ramadhan et al. (2015) & $130,495,143$ & 9,666 \\
Habitat Sumberdaya ikan & $9,698,306$ & Barbier et al. (2011) & $18,312,341$ & 1,356 \\
Sosial budaya & $87,349,303$ & Ramadhan et al. (2015) & $164,932,954$ & 12,217 \\
Total & $\mathbf{3 1 3 , 7 4 0 , 4 3 8}$ & & $313,740,438$ & $\mathbf{2 3 , 2 4 0}$ \\
\hline
\end{tabular}

Sumber: Ramadhan et al. (2015) dan Barbie et al. (2011)

Tabel 5. Perhitungan Kerugian Masyarakat

\begin{tabular}{lccrr}
\hline Nilai Pemanfaatan & (Rp/Ha/Tahun & Sumber & Untuk Luasan & USD \\
& $\mathbf{2 0 1 7 )}$ & & $\mathbf{1 , 8 8 8 2 ~ H a ~ ( R p ) ~}$ & 1,119 \\
\hline Penangkapan & $7,999,245$ & Ramadhan et al. (2015) & $15,104,174$ & 36 \\
Pariwisata & 254,078 & Dohar et al. (2006) & 479,751 & $\mathbf{1 5 . 5 8 3 . 9 2 5}$ \\
Total & $\mathbf{8 , 2 5 3 , 3 2 3}$ & & $\mathbf{1 5 4}$ \\
\hline
\end{tabular}

Sumber: Ramadhan et al. (2015) dan Barbie et al. (2011) 


\section{Kerugian Masyarakat}

Kerugian ekonomi masyarakat akibat kerusakan terumbu karang merupakan dampak ekonomi yang dirasakan oleh pemanfaat (masyarakat sekitar lokasi kejadian). Dampak ekonomi terhadap masyarakat dalam kajian ini berupa potensi hilangnya pendapatan masyarakat/ pemerintah dari aktivitas penangkapan ikan dan pariwisata. Untuk memperoleh besaran kerugian terhadap masyarakat adalah menghitung besaran nilai manfaat yang diperoleh oleh masyarakat ketika memanfaatkan barang dan jasa dari ekosistem terumbu karang yang dihitung dari biaya transaksi. Menurut Rosales (2006), komponen estimasi perhitungan kerusakan terumbu karang yang ditimbulkan oleh tabrakan kapal di Tubbataha Reef National Marine Park dihitung dari Total Economic Value (TEV) ekosistem terumbu karang yang hanya dilihat dari pendekatan produksi. Pendekatan produksi adalah estimasi besaran barang dan jasa ekosistem terumbu karang yang terukur karena adanya transaksiekonomi. Oleh karena itu, dalam perhitungan kerugian terhadap masyarakat diukur dari nilai manfaat langsung yang berasal dari pariwisata dan penangkapan ikan saja. Komponen estimasi perhitungan kerusakan terumbu karang dihitung dari Total Economic Value (TEV). Pendekatan yang digunakan yaitu, Effect on Production dan Travel Cost Method.

Jika digabung jumlah kerugian ekonomi terumbu karang yang rusak akibat tabrakan kapal Caledonian Sky minimal sebesar 23 juta dolar tanpa memasukan biaya pelaksanaan penyelesaian sengketa lingkungan hidup karena ini adalah pengeluaran riil yang dikeluarkan ketika proses ini berlangsung. Untuk lebih detail tertuang dalam Tabel 6 .

\section{Aspek Hukum Dan Kebijakan}

Tindakan Hukum yang dapat dilakukan oleh Pemerintah Indonesia terhadap Kapal Pesiar MV Caledonia Sky yang Karam di Perairan Raja Ampat dan mengakibatkan rusaknya Terumbu Karang di Raja Ampat Papua seluas lebih kurang $18.882 \mathrm{~m}^{2}$.

\section{I.Legal Brief (Kasus Posisi)}

Kapal pesiar MV Caledonian Sky dari Inggris berbendera Bahama, Amerika Serikat (AS), dengan bobot $4.200 \mathrm{GT}$, pada 3 Maret 2017 lalu Karam di Perairan Raja Ampat Papua sehingga mengakibatkan terumbu karang yang ada di Raja Ampat, Papua, rusak berat.

\section{Legal Question (Pertanyaan Hukum)}

Dapatkah Pemerintah Indonesia menggugat ganti rugi atas kerusakan Terumbu Karang di Perairan Raja Ampat yang disebabkan oleh Kapal MV Caledonia Sky.

\section{Legal Audit (Penelusuran Hukum)}

Penelusuran hukum yang dijadikan landasan untuk pengajuan klaim kerugian ekonomi rusaknya terumbu karang adalah UU No. 31/2004 jo UU No. 45/2009, tentang Perikanan, Pasal 87 (Ayat 2) jo Pasal 14 Ayat (4) (denda maksimal Rp. 500.000.000,- dan pidana penjara maksimum 1 tahun) dan UU No. $32 / 2009$, tentang Perlindungan dan Pengelolaan Lingkungan Hidup, Pasal 87, Ayat (1) dimana (1) Setiap penanggung jawab usaha dan/atau kegiatan yang melakukan perbuatan melanggar hukum berupa pencemaran dan/atau perusakan lingkungan hidup yang menimbulkan kerugian pada orang lain atau lingkungan hidup wajib membayar ganti rugi dan/atau melakukan tindakan tertentu. Peraturan Daerah Kabupaten Raja Ampat No. 27/2008, tentang Kawasan Konsevasi Laut Daerah Kabupaten Raja Ampat. (denda maksimal Rp. 50.000.000,- dan pidana kurungan maksimum 6 bulan).

\section{Legal Opinion (Pendapat Hukum)}

Ganti rugi dapat dituntut berdasarkan sanksi yang sudah diatur dalam regulasi nasional. Proses ini membutuhkan waktu yang tidak sebentar dan biaya yang dikeluarkan tidak sedikit untuk berperkara di pengadilan. Kemungkinan tidak mendapatkan ganti rugi secara maksimal tetap ada. Dasarnya adalah harus melihat kemungkinan adanya kelalaian juga dari pengelola taman nasional di Raja Ampat. Kondisi ini dapat dijadikan fakta hukum baru untuk mengurangi besarnya nilai tuntutan ganti rugi pemerintah. Pemerintah tetap dapat 
mengajukan tuntutan sebesar-besarnya karena menurut teori hukum hal ini masih dapat dilakukan, dengan ketentuan siapa yang mendalilkan dia harus membuktikan. Posisi indonesia harus dapat memberikan bukti yang kuat untuk dapat meminta ganti rugi secara maksimal. (meskipun lemah posisi Indonesia tetapi masih bisa diupayakan, karena celah sekecil apapun di dalam ilmu hukum bisa merubah fakta hukum). Jika pemerintah ingin mengajukan gugatan kerugian lebih besar dari denda yang ditetapkan di dalam UU tetap dapat dilakukan, meskipun landasan hukumnya lemah. Menurut teori hukum siapa yang mendalilkan harus membuktikan. Tuntutan ganti rugi sebesar apapun masih dapat dilakukan pemerintah, dengan syarat memiliki bukti yang kuat. Tekanan politik juga bisa menguatkan posisi Indonesia untuk mendapatkan ganti rugi secara maksimal. Langkah hukum terbaik adalah diselesaikan secara musyawarah di luar pengadilan untuk melakukan negosiasi terhadap kesepakatan ganti rugi. Kemungkinan hukum adanya implikasi dengan berperkara di pengadilan, adalah tindakan balasan dari negara Amerika pada sektor lain yang dapat menganggu hubungan kedua negara.

\section{Tabel 6. Penghitungan Kerugian Ekonomi Rusaknya Terumbu Karang Akibat Tabrakan Caledonian Sky.}

\begin{tabular}{|c|c|c|c|}
\hline No & Jenis Biaya & Nilai (Rp) & Nilai (USD) \\
\hline \multirow[t]{4}{*}{1} & $\begin{array}{l}\text { Pelaksanaan penyelesaian sengketa lingkungan } \\
\text { hidup }\end{array}$ & & \\
\hline & a. Biaya verifikasi lapangan² & - & - \\
\hline & b. Biaya analisa data ${ }^{2}$ & - & - \\
\hline & $\begin{array}{l}\text { c. Biaya ahli dan pengawasan pelaksanaan } \\
\text { pembayaran kerugian-kerugian }\end{array}$ & - & - \\
\hline \multirow[t]{10}{*}{2} & Pemulihan/Restorasi & & \\
\hline & I. Kerusakan $100 \%(1,3270$ ha $)$ & & \\
\hline & $\begin{array}{l}\text { a. Biaya kompensasi/restorasi perbaikan lingkungan } \\
\text { hidup/ terumbu karang }{ }^{1}\end{array}$ & - & - \\
\hline & b. Biaya monitoring jangka panjang restorasi2 & $157,319,855,785$ & $11,653,323$ \\
\hline & II. Kerusakan $50 \%(0,5612$ ha $)$ & & \\
\hline & $\begin{array}{l}\text { a. Biaya kompensasi/restorasi perbaikan lingkungan } \\
\text { hidup/ terumbu karang }{ }^{1}\end{array}$ & - & - \\
\hline & b. Biaya monitoring jangka panjang restorasi² & - & - \\
\hline & III. Kerusakan $50 \%$ (0,5612 ha) & $48,030,789,035$ & 557,836 \\
\hline & $\begin{array}{l}\text { a. Biaya kompensasi/restorasi perbaikan lingkungan } \\
\text { hidup/ terumbu karang }{ }^{1}\end{array}$ & - & - \\
\hline & b. Biaya monitoring jangka panjang restorasi² & - & - \\
\hline \multirow[t]{4}{*}{3} & Kerugian ekosistem & $130,495,143$ & 9,666 \\
\hline & a. Proteksi lingkungan pesisir & $18,312,341$ & 1,356 \\
\hline & b. Habitat sumberdaya ikan & $164,932,954$ & 12,217 \\
\hline & c. Sosial budaya. & - & - \\
\hline \multirow[t]{4}{*}{4} & Kerugian masyarakat akibat kerusakan & & \\
\hline & a. Penangkapan & $15,104,174$ & 1,119 \\
\hline & b. Pariwisata & 479,751 & 36 \\
\hline & Total $^{3}$ & $205,679,969,183$ & $15,235,553$ \\
\hline
\end{tabular}

Sumber: Hasil Estimasi Perhitungan (2017).

Keterangan:

1. 1 USD = Rp. Rp. 13.500 (Maret 2017)

2. Waktu project restorasi untuk luasan $1,8882 \mathrm{Ha}$ adalahselama 10 tahun.

3. Layanan jasa (service gain) terumbu karang yang rusak akan kembali seperti semula setelah 25 tahun

4. sudah memasukan biaya operasional restorasi selama proses restorasi dalam satuan biaya restorasi'.

5. Belum dimasukkan kedalaman perhitungan².

6. Angka sementara (belum memasukkan komponen biaya pelaksanaan penyelesaian sengketa lingkungan hidup, biaya monitoring jangka panjang) ${ }^{3}$.

7. Discount Factor untuk sumberdaya alam $3 \%$ (Office Management of Budget, USA), Discount Factor terhadap mata uang $7,5 \%$ (BANK INDONESIA). 
Tabel 7. Landasan Regulasi Dalam Pengajuan Klaim Kerugian Ekonomi Kerusakan Terumbu Karang Akibat Tabrakan Kapal Pesiar Caledonia Sky di Raja Ampat.

\begin{tabular}{l} 
Regulasi \\
\hline UU No. 31/2004, \\
tentang Perikanan jo UU \\
No. 45/2009, tentang \\
Perubahan atas Undang- \\
Undang No. 31 Tahun
\end{tabular}

2004, tentang Perikanan

UU No. 9/1990, tentang Kepariwisataan

UU No. 32/2009, tentang Perlindungan dan Pengelolaan Lingkungan Hidup

\section{(1)}

Pasal 87, Ayat

(1)

Pasal 87 jo
Pasal 14 Aya

(4)

(4)

Sasal 87

\section{Keterangan}

Harus dilihat pelanggarannya

(1) Setiap orang yang dengan sengaja di wilayah pengelolaan perikanan Republik Indonesia merusak plasma nutfah yang berkaitan dengan sumber daya ikan sebagaimana dimaksud dalam Pasal 14 ayat (4), dipidana dengan pidana penjara paling lama 2 (dua) tahun dan denda paling banyak Rp1.000.000.000,00 (satu miliar rupiah)

(2) Setiap orang yang karena kelalaiannya di wilayah pengelolaan perikanan Republik Indonesia mengakibatkan rusaknya plasma nutfah yang berkaitan dengan sumber daya ikan sebagaimana dimaksud dalam Pasal 14 ayat (4), dipidana dengan pidana penjara paling lama 1 (satu) tahun dan denda paling banyak Rp. 500.000.000,00 (lima ratus juta rupiah).

\section{Pasal 14 Ayat (4)}

(4) Setiap orang dilarang merusak plasma nutfah yang berkaitan dengan sumber daya ikan

Pasal 35, Ayat 35

(1) Barang siapa melakukan perbuatan melawan hak, dengan sengaja merusak, mengurangi; mengurangi nilai, memisahkan, atau membuat tidak dapat berfungsi atau tidak dapat berfungsinya secara sempurna suatu objek dan daya tarik wisata, atau bangunan obyek dan daya tarik wisata, atau bagian dari bangunan objek dan daya tarik wisata, dipidana dengan pidana penjara paling lama 5 (lima) tahun dan/atau denda setinggi-tingginya Rp. 50.000.000,00 (lima puluh juta rupiah).

Pasal 87

(1) Setiap penanggung jawab usaha dan/atau kegiatan yang melakukan perbuatan melanggar hukum berupa pencemaran dan/atau perusakan lingkungan hidup yang menimbulkan kerugian pada orang lain atau lingkungan hidup wajib membayar ganti rugi dan/atau melakukan tindakan tertentu.

\section{Pasal 24 (Ayat Pasal 24}

1) jo Pasal 22

(1) Setiap orang atau badan hukum yang melanggar ketentuan sebagaimana dimaksud dalam Pasal 22 dan Pasal 23 dikenakan pidana kurungan paling lama 6 (enam) bulan dan atau denda paling banyak Rp. 50.000.000,- (lima puluh juta rupiah)

(2) Tindak pidana sebagaimana dimaksud pada ayat (1) adalah pelanggaran

Pasal 22

(1) Setiap orang atau badan hukum dilarang melakukan kegiatan yang dapat mengakibatkan perubahan terhadap ekosistem dan keutuhan KKLD (Kawasan Konservasi Laut Daerah)

(2) Perubahan terhadap keutuhan KKLD sebagaimana dimaksud pada ayat (1) meliputi mengurangi, menghilangkan fungsi dan luas KKLD

termasuk unsur kesengajaan atau kelalaian)
Ampat No. 27/2008

Konsevasi Laut Daerah

Kabupaten Raja Ampat 


\section{KESIMPULAN DAN IMPLIKASI KEBIJAKAN}

\section{Kesimpulan}

Estimasi jumlah kerugian ekonomi rusaknya terumbu karang akibat tabrakan Kapal Pesiar Caledonian Sky di Raja Ampat sebesar 15 juta USD dengan luasan terdampak total $18.882 \mathrm{~m}^{2}$ termasuk kerusakan $100 \%$ seluas 1,3270 ha dan $50 \%$ seluas 0,5612 ha.

\section{Implikasi Kebijakan}

Kebijakan yang dapat diambil sebagai opsi pemerintah untuk menghadapi kerusakan terumbu karang akibat tabrakan Kapal Pesiar Caledonian Sky adalah mempertimbangkan untuk mengadakan negosiasi penyelesaian sengketa tentang tuntutan kerugian kepada perusahaan kapal pesiar Inggris Caledonian Sky atas rusaknya terumbu karang di luar pengadilan dan mempertimbangkan langkah hukum untuk menuntut ganti rugi kepada perusahaan kapal pesiar Inggris Caledonian Sky sesuai dengan hukum yang berlaku di Indonesia.

\section{UCAPAN TERIMA KASIH}

Terima kasih diucapkan kepada Balai Besar Riset Sosial Ekonomi KP-BRSDM KP yang telah membiayai kegiatan penelitian ini, kepada Conservation International (Cl) dan kepada Kementerian Koordinator Bidang Maritim dalam hal ini diwakili oleh Muhammad Burhanuddin Borut yang telah memberikan data dan informasi yang sangat penting dalam kegiatan penelitian ini.

\section{DAFTAR PUSTAKA}

Barbier. E. B., S. D.Hacker, C. Kennedy, E. W. Koch, A. C.Stier and B. R. Silliman. 2011. The Value of Estuarine and Coastal Ecosystem Services. Ecological Monographs Volume 81 Nomor 2 2011. Pp: 169-193.

Bayraktarov,E.,M.I.Saunders,S.Abdullah,M.Milis,J. Beher,H.P.Possingham,P.J.Mumby, and C.E.Lovelock. 2016. The Cost and Feasibility of Marine Coastal Restoration. Ecological Applications. Volume 26 Nomor 42016. pp.1055-1074.

Dohar, A.G. dan D. Anggraeni. 2006. Valuasi Ekonomi Sumberdaya Alam di Kepulauan Raja Ampat.
Conservation International Indonesia dan Universitas Negeri Papua.

Dunn, W. N. 2003. PengantarAnalisis Kebijakan Publik edisi kedua. Wibawa S, Asitadani D, Hadna $A H$, Purwanto EA, penerjemah: Darwin $M$, editor. Terjemahan dari Public Policy Analysis: An Introduction. Gajahmada University Press, Yogyakarta.

Edwards, A.J. and E. D. Gomez. 2007. Reef Restoration Concepts and Guidelines: making sensible management choices in the face of uncertainty. Capacity Building for Management Programme/Coral Reef Targeted Research: St. Lucia.

Fauzi, A. 2014. Valuasi Ekonomi Dan Penilaian Kerusakan Sumber Daya Alam dan Lingkungan : Berbagai Informasi Terkait Valuasi Ekonomi Disajikan dengan Dasar Teori yang Kuat dan Metode Serta Contoh-Contoh Aplikasinya. IPB Press. Bogor. 246 halaman.

Gouze, M., E. I. Otto, D. Olsudong and G. Mereb. 2015. Quantitative assessment of coral-reef damage caused by the Palau Siren grounding in Koror State Southern Lagoon. Palau International Coral Reef Center Technical Report No 15-16. Pp 1-21.

Islamy, M. I. 1994. Prinsip-Prinsip Perumusan Kebijakan Negara. Bumi Aksara. Jakarta. 131 Halaman.

MacNeil, M. A., N. A. J. Graham, J. E.Cinner, S. K. Wilson, I. D.Williams, J. Maina, S. Newman, A.M. Freidlander, S. Jupiter, N.V.C. Polunium and T. McClanahan. 2015. Recovery Potential of The World 's Coral Reef Fishes. Nature Volume 52016 Aprli 2015. Pp: 341-357

Parson, W. 2008. Public Policy: Pengantar Teori dan Praktik Analisis Kebijakan. Kencana. Jakarta. 686 Halaman.

Ramadhan, A., Lindawati dan N. Kurniasari. 2016. Nilai Ekonomi Ekosistem Terumbu Karang di Wakatobi. Jurnal Sosial Ekonomi Tahun 2016. Pusat Penelitian Sosial Ekonomi Kelautan Perikanan

Rosales. 2006. Estimating Appropriate Fines for Ship Grounding Violations in Tubbataha Reef National Marine Park. Conservation International Philippines. Pp 1-18

Subarsono. A. G. 2013. Analisis Kebijakan Publik Konsep, Teori dan Aplikasi. Pustaka Pelajar. Yogyakarta. 154 Halaman.

Wirartha, I. M. 2006. Metodologi Penelitian Sosial Ekonomi. ANDI. Yogyakarta. 390 halaman. 
Woodward, A. and H. Kathy. 2011. Monitoring habitat restoration projects: U.S. Fish and Wildlife Service Pacific Region Partners for Fish and Wildlife Program and Coastal Program Protocol: U.S. Geological Survey Techniques and Methods 2-A11, $36 \mathrm{p}$

Peraturan Menteri Kelautan Perikanan Nomor 24/Permen-KP/2016 tentang Tata Cara Rehabilitasi Wilayah Pesisir dan Pulau-Pulau Kecil

Peraturan Menteri Lingkungan Hidup Nomor 7 Tahun 2014 tentang Kerugian Lingkungan Hidup Akibat Pencemaran dan/ atau Kerusakan Lingkungan Hidup 